\title{
Nodularia spp. (Cyanobacteria) incorporate leucine but not thymidine: importance for bacterial-production measurements
}

\author{
Susanna Hietanen ${ }^{1, *}$, Jaana Maritta Lehtimäki ${ }^{2}$, Liisa Tuominen ${ }^{1}$, Kaarina Sivonen $^{2}$ \\ Jorma Kuparinen $^{3}$ \\ ${ }^{1}$ Finnish Institute of Marine Research, PO Box 33, 00931 Helsinki, Finland \\ ${ }^{2}$ Department of Applied Chemistry and Microbiology, Division of Microbiology, PO Box 56, Biocentre Viikki, \\ 00014 University of Helsinki, Finland \\ ${ }^{3}$ Department of Ecology and Systematics, Division of Hydrobiology, PO Box 17, 00014 University of Helsinki, Finland
}

\begin{abstract}
Six strains of Nodularia spp., both toxic and nontoxic, were tested for their ability to incorporate leucine and thymidine. All axenic cyanobacterial strains studied showed high leucine incorporation (1.4 to $12 \mathrm{pmol} \mu \mathrm{g} \mathrm{chl} \mathrm{a}^{-1} \mathrm{~h}^{-1}$ at a concentration of $212 \mathrm{nM}$ leucine), whereas thymidine was either taken up at a very low rate or not at all ( 0 to $0.2 \mathrm{pmol}$ $\mu \mathrm{gchl} \mathrm{a}^{-1} \mathrm{~h}^{-1}$ at a concentration of $121 \mathrm{nM}$ thymidine). We therefore recommend using the thymidine incorporation method instead of that of leucine for measuring heterotrophic bacterial production during cyanobacterial blooms.
\end{abstract}

KEY WORDS: Leucine - Thymidine - Bacterial production Cyanobacteria

Resale or republication not permitted without written consent of the publisher

Bacterial production is routinely measured in aquatic ecosystems. The most commonly used methods nowadays are the ${ }^{3} \mathrm{H}$-thymidine incorporation method by Fuhrman \& Azam (1980), and the ${ }^{3} \mathrm{H}$ - or ${ }^{14} \mathrm{C}$-leucine incorporation method by Kirchman et al. (1985). The methods have been criticised and subsequently modified, but the principles behind them have not dramatically changed. Azam \& Fuhrman (1984) summarised the widely accepted criteria for an exemplary method to estimate bacterial production. They stated that the method used should be specific for heterotrophic bacteria and it should not rely on balanced growth. Furthermore, the growth rates should not be affected by procedures involved in measurements, and if any conversion factors are needed, these should be easy and reliable to produce.

*E-mail: susanna.hietanen@fimr.fi
The ${ }^{3} \mathrm{H}$-thymidine method is based on measuring DNA production and consequently, cell division. Thymidine has only 1 function in a cell, namely participation in DNA synthesis, which makes it a good tool in bacterial production measurements. Several authors have demonstrated that thymidine in nanomolar concentrations is exclusively taken up by heterotrophic bacteria, not by cyanobacteria, algae or zooplankton (Fuhrman \& Azam 1982, Bern 1985, Robarts \& Wicks 1989, Pedrós-Alió et al. 1993, Lehtimäki et al. 1997). However, it has also been revealed that not all heterotrophic bacteria can incorporate thymidine (Pollard \& Moriarty 1984, Davis 1989, Jeffrey \& Paul 1990, Robarts \& Zohary 1993). In addition, the method relies on using conversion factors when translating the thymidine incorporation into cells created and further, the cells to biomass (carbon and nitrogen) produced. These conversion factors have been shown to vary largely in different environments and there is still controversy as to the best method for generating such factors. In addition to these major drawbacks, questions have also arisen about unspecific labelling after degradation of ${ }^{3} \mathrm{H}$-thymidine in cells (Pollard \& Moriarty 1984, Riemann 1984), proper methods to extract and purify DNA from cells (reviewed by Robarts \& Zohary 1993), intra- and extracellular dilution of the isotope (Moriarty 1986, Jeffrey \& Paul 1988) and the role of viral DNA synthesis in infected cells (Bratbak et al. 1992).

Because of these uncertainties with the thymidine method, the leucine incorporation method has gained more prevalence in recent years. The ${ }^{3} \mathrm{H}$ - or, nowadays more commonly, ${ }^{14} \mathrm{C}$-leucine method is based on measuring protein synthesis in the cells. The main advan- 


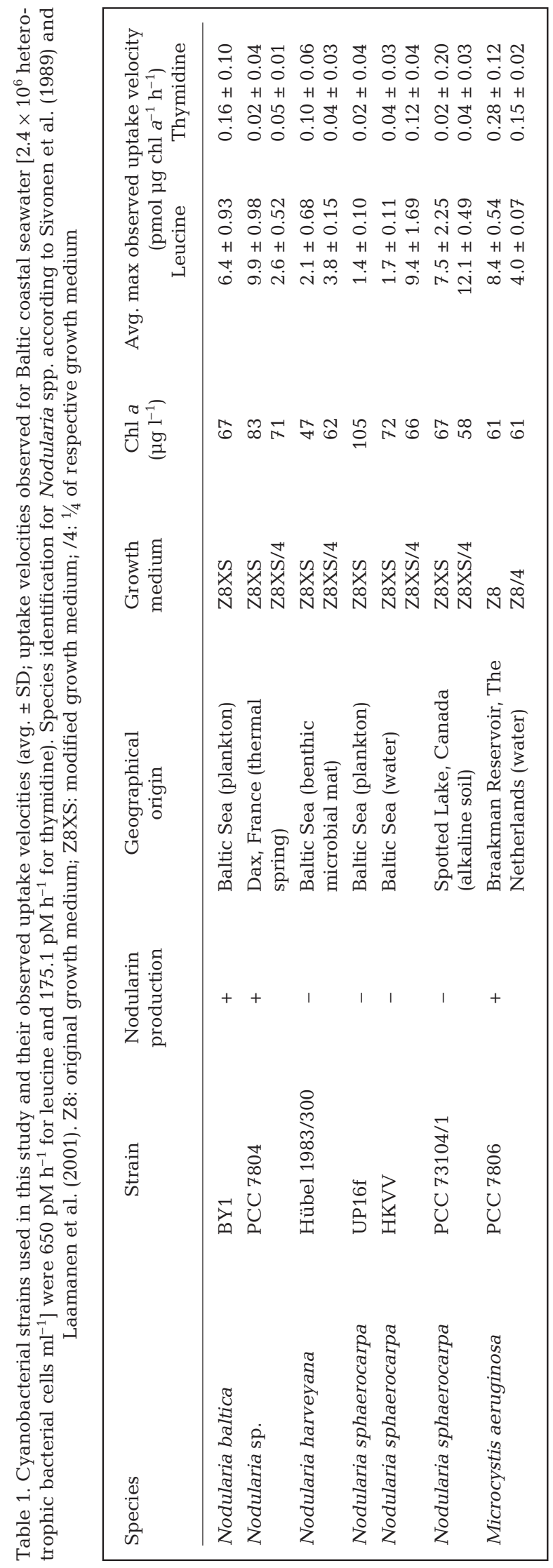

tage of the leucine over the thymidine method is that for measuring heterotrophic bacterial carbon production, no experimental conversion factors are needed, as the amount of leucine in bacterial proteins, the amount of protein per cell and the relation of carbon to protein are all constant in marine bacterial assemblages (Simon \& Azam 1989). Furthermore, the leucine method is an order of magnitude more sensitive than the thymidine method, thus allowing measurements in low-activity environments, and the isotope dilution can be measured relatively easily (Simon \& Azam 1989). Leucine in nanomolar concentrations was also considered to be taken up exclusively by heterotrophic bacteria (Kirchman et al. 1985, Riemann \& Azam 1992), until Kamjunke \& Jähnichen (2000) reported significant leucine incorporation of axenic culture of the cyanobacterium Microcystis aeruginosa strain PCC 7806. They concluded that measurements with leucine in waters dominated by $M$. aeruginosa might yield overestimates of bacterial production. To date, only this one cyanobacterium strain belonging to the unicellular non-heterocystous genus has been shown to incorporate leucine. We tested whether the filamentous, heterocystous Nodularia spp., cyanobacteria that bloom annually in the Baltic Sea, also incorporate leucine, and whether thymidine incorporation could be recommended as a method of choice during such a bloom.

Materials and methods. Leucine and thymidine incorporation of 6 axenic nodularin-producing and non-toxic Nodularia spp. strains were tested (Table 1). The Microcystis aeruginosa strain PCC 7806 was used as a positive control for leucine incorporation (Kamjunke \& Jähnichen 2000), and coastal seawater (ca. $2.4 \times 10^{6}$ heterotrophic bacterial cells $\mathrm{ml}^{-1}$ ) was used as positive control for both leucine and thymidine incorporation. The axenity of strains was confirmed with an epifluorescence microscope (Leitz Aristoplan) after acridine orange staining. The Nodularia spp. strains were grown in a modified Z8 medium with salt and without nitrogen (Sivonen et al. 1989), and the $M$. aeruginosa strain was grown in an original Z8 medium without salt and with nitrogen (Rippka 1988 and references therein). In addition, 5 of these strains were grown in media that contained only $1 / 4$ of the components of original growth media in order to find out whether possible substrate incorporation was related to nutrient status of the growth media. Cultures were incubated in a programmable growth cabinet (Sanyo) under illumination of $100 \mu \mathrm{mol} \mathrm{s} \mathrm{s}^{-1} \mathrm{~m}^{-2}$ on an 18:6 h light:dark cycle. Temperature was $25^{\circ} \mathrm{C}$ during the daytime and $20^{\circ} \mathrm{C}$ during the night. Incorporation experiments were done using exponentially growing cultures that were diluted with sterile growth media to

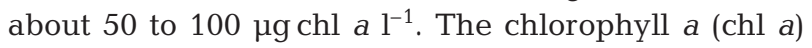


concentrations of the final dilutions (Table 1) were measured from $50 \mathrm{ml}$ samples filtered on glass-fibre filters (GF/F, Whatman). Pigments were extracted $\left(24 \mathrm{~h}, 4^{\circ} \mathrm{C}\right)$ with $10 \mathrm{ml}$ of $94 \%(\mathrm{v} / \mathrm{v})$ ethanol and determined fluorometrically (Perkin Elmer LS-2).

To evaluate leucine and thymidine uptake rates, each cyanobacterial strain (grown in both nutrientrich and nutrient-poor media), as well as the control seawater (ca. $2.4 \times 10^{6}$ heterotrophic bacterial cells $\mathrm{ml}^{-1}$ ), was treated separately (no dual labelling) with 3 concentrations of the 2 substrates $(69,121$ and $212 \mathrm{nM}$ for leucine [Amersham, $295 \mathrm{mCi} \mathrm{mmol}^{-1}$ ]; 13, 30 and $121 \mathrm{nM}$ for thymidine [PerkinElmer Life Sciences, 85.7 $\mathrm{Ci} \mathrm{mmol}^{-1}$ ]. These ranges cover the isotope concentrations most often used in pelagic samples in both oligotrophic and eutrophic environments. Samples of each strain $(5 \mathrm{ml} ; 3$ replicates, 1 blank [killed with formalin before adding the isotope]) were incubated with the substrates in autoclaved scintillation vials in darkness at room temperature for $1 \mathrm{~h}$. After terminating the incubations with formalin, the samples were filtered immediately (leucine) or within $20 \mathrm{~h}$ (thymidine) in ice-cold conditions on cellulose-nitrate filters (Ø $25 \mathrm{~mm}$, pore size $0.2 \mu \mathrm{m}$, Sartorius) that had been briefly soaked in ice-cold $5 \%(\mathrm{w} / \mathrm{v})$ TCA (trichloroacetic acid) before use. Sample vials were rinsed with $2 \mathrm{ml}$ of ice-cold $5 \%$ TCA and these solutions were added on filters. Then, filtration funnels were rinsed with $2 \mathrm{ml}$ of ice-cold $5 \%$ TCA and removed. Cells on the filters were extracted 5 times with $1 \mathrm{ml}$ of ice-cold $5 \%$ TCA (Riemann 1984, Børsheim 1990) and then the filters were placed in scintillation vials. To dissolve the filters, $10 \mathrm{ml}$ of scintillation cocktail (Insta-Gel Plus, Packard) was added into vials that were left to stand at room temperature overnight. The next day, the vials were shaken vigorously before assaying the radioactivity in a scintillation counter (Wallac Winspectral 1414).

Results and discussion. All strains studied incorporated leucine (Fig. 1). The incorporation rate varied between the strains and it was significantly $(p<0.01)$ higher for Nodularia sp. starved of nutrients (nutrientpoor media) than for Nodularia sp. grown in abundant nutrient conditions in one case (Strain HKVV), and significantly lower in another (Strain PCC 7804) of the 4 Nodularia spp. strains tested. For the Microcystis aeruginosa, the incorporation rate was significantly higher in the culture grown in abundant nutrient conditions (Fig. 1). Evidently, most of the strains were not saturated even at the highest leucine concentration used (Fig. 1a-c,e,f). The blank values of cyanobacteria samples were on average $45 \%$ of the sample values (disintegrations per minute [DPM]-difference between blanks and samples ranging from 52 to 2685 DPM, average 699 DPM) whereas the blanks were $15 \%$ of the sample values in seawater (DPM-difference between blanks and samples 1792 to 2115 DPM, average 1965 DPM). High blank values may be a result of the isotope adsorption to the cyanobacterial surfaces that often are covered with mucus (Schuster et al. 1998). Adsorption can be expected to be similar in both blanks and samples, and hence blank subtraction provides a reliable elimination of adsorbed (not incorporated) leucine in calculations. Such adsorption might also explain why the cyanobacterial cultures were not saturated even at the high leucine concentrations used. Only after all the adsorption sites are occupied will there be free leucine left for uptake (Schuster et al. 1998). Under such non-saturated conditions internal and external isotope dilution can also be expected to occur, and the measured values may be underestimates of the real uptake capacity.

On the contrary, thymidine was either incorporated at a very low rate (Fig. 2a, c,d,f), or not incorporated at all (Fig. 2b,e), blanks giving higher values than the samples. Some of the strains seemed not to be saturated even at the extremely high thymidine concentration used, although the incorporation rate was very low (Fig. 2a,c,d,f). The blank values were on average $89 \%$ of the cyanobacterial sample values, while in seawater they were $9 \%$ of the sample. The DPM values after blank subtraction averaged 338 at the lowest and 3334 at the highest incubation concentration when negative values were included, and 555 and 4187, respectively, when negative values were marked 0 . The corresponding average values in the seawater sample (ca. $2.4 \times 10^{6}$ heterotrophic bacterial cells ml- ${ }^{-1}$ ) were 35979 at the lowest $(13 \mathrm{nM})$ and 119385 at the highest (121 nM) incubation concentration. The adsorption to mucus has been shown to be even more dramatic for thymidine than for leucine (Schuster et al. 1998), giving a credible explanation to non-saturable uptake kinetics recorded in this experiment.

The leucine incorporation per $\mu \mathrm{g}$ chl a varied from 0.95 to $12.4 \mathrm{pmol} \mathrm{h}^{-1}$ at the highest incubation concentration $(212 \mathrm{nM})$. Some strains clearly were not saturated and therefore the observed uptake rates cannot be considered maximal. A conservative estimate of the effect of cyanobacteria on the heterotrophic bacterial production measurements using the leucine method can be calculated. In late summer $1990(1.8 \mu \mathrm{g} \mathrm{chl} \mathrm{a}$ $\left.\mathrm{l}^{-1}\right)$, heterotrophic bacteria incorporated $90 \mathrm{pM}$ leucine $\mathrm{h}^{-1}$ in the Gulf of Finland (Heinänen \& Kuparinen 1992). In the Gulf of Finland, late summer cyanobacterial blooms have been shown to reach concentrations of up to $18 \mu \mathrm{g} \mathrm{chl} \mathrm{a} \mathrm{l}^{-1}$ (Heinänen et al. 1995). At such a chl a concentration, the leucine incorporation of cyanobacteria ( 17 to $218 \mathrm{pM} \mathrm{h}^{-1}$ ) would be equal to or even higher than that of the heterotrophic bacteria. Kamjunke \& Jähnichen (2000) calculated the overesti- 
a

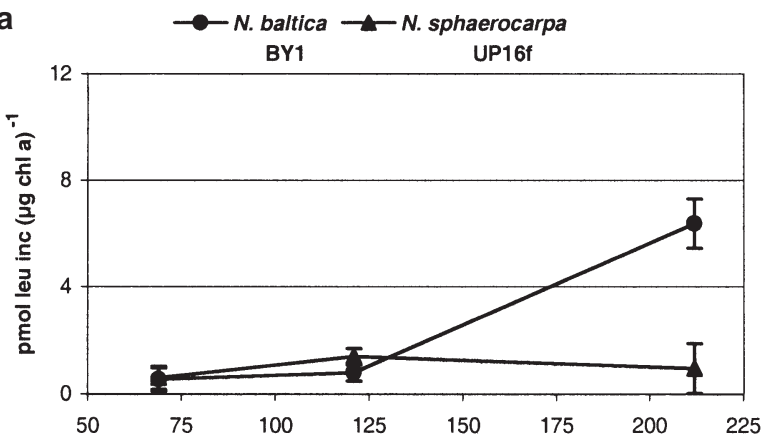

c

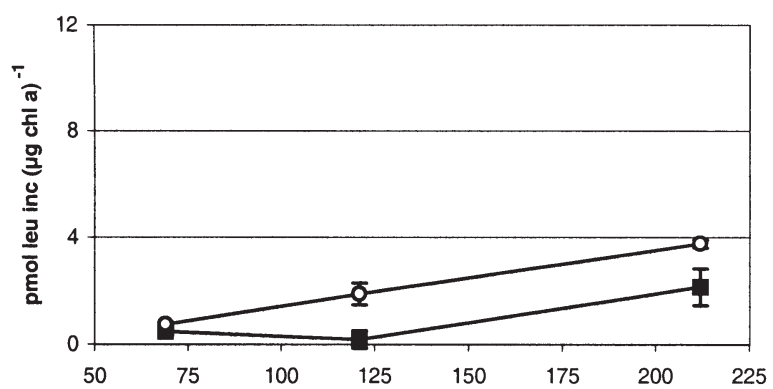

$\mathbf{e}$

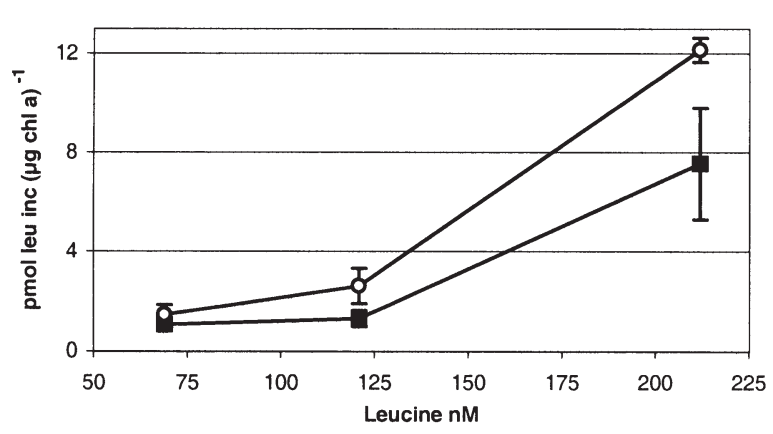

b

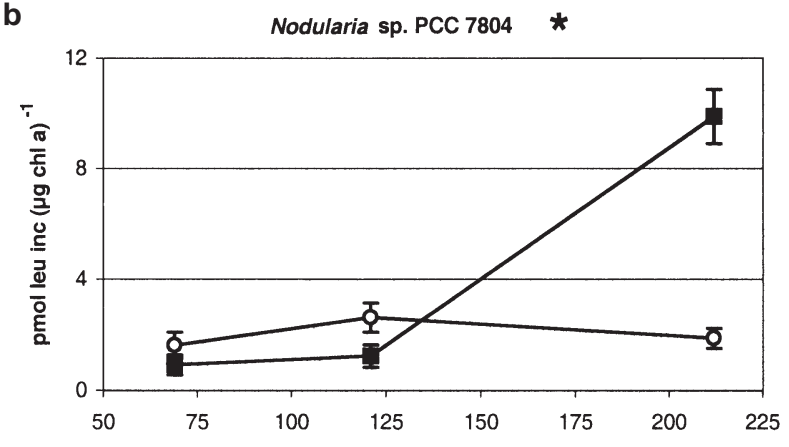

d

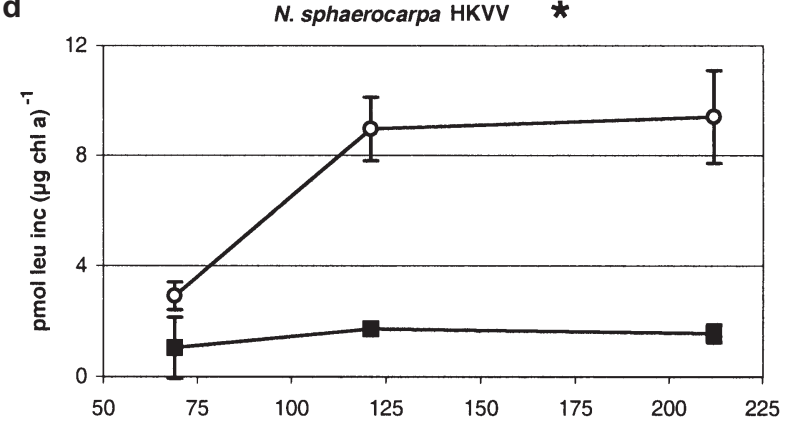

f

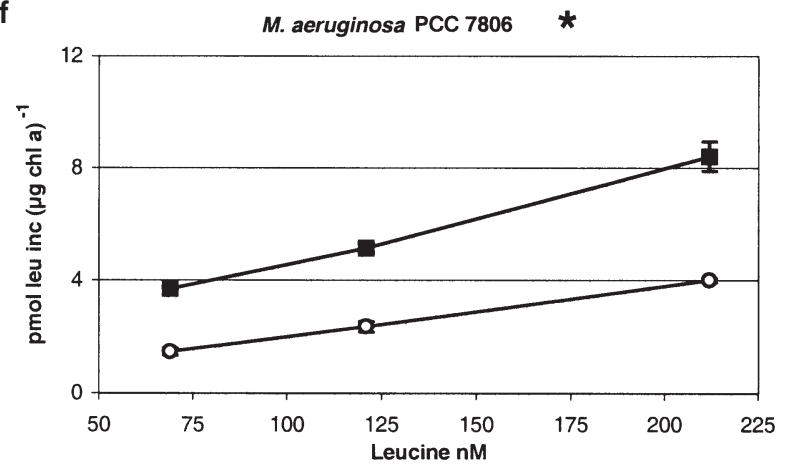

Fig. 1. Cyanobacterial (Nodularia spp. and Microcystis sp.) leucine uptake velocity (pmol leucine $\mu g \mathrm{chl}^{-1} \mathrm{~h}^{-1}$ ) at various leucine concentrations. Cyanobacteria grown in nutrient-rich $(\square)$ and nutrient-poor (O) growth media. Error bars \pm SD. ${ }^{*}$ Significant $(\mathrm{p}<0.01)$ differences in uptake between the cultures grown in nutrient rich and nutrient poor media

mate caused by a freshwater Microcystis aeruginosa bloom in a eutrophic lake to be in the same range (20 to $140 \%$ ). They pointed out that during maximum biomass, cyanobacteria often are already senescent, and therefore less likely to actively incorporate leucine, but that they nevertheless may cause significant overestimation of heterotrophic production. In our experiments the $M$. aeruginosa strain incorporated leucine at a rate $10 \%$ of that measured by Kamjunke \& Jähnichen (2000). Obviously the growth conditions (nutrients, light, growth phase) have a large effect on incorporation. We measured the cyanobacterial leucine and thymidine incorporation in the dark, as this is the routine method for measuring heterotrophic bacterial production. Kamjunke \& Jähnichen (2000) reported enhanced leucine incorporation by $M$. aeruginosa in the light, and this effect must be kept in mind if light incubations for bacterial production measurements will begin on a routine basis as suggested by Morán et al. (2001).

Kamjunke \& Jähnichen (2000) suggested that the leucine uptake by Microcystis aeruginosa PCC 7806 could be related to the toxin production, as leucine is one constituent of microcystin-LR. Several strains of Nodularia spp. produce the toxin nodularin, which does not contain leucine, and all the Nodularia spp. strains tested here incorporated leucine independent from their ability to produce nodularin. Leucine did not seem to be taken up as a source of nitrogen or carbon either as the uptake was both significantly higher 
a

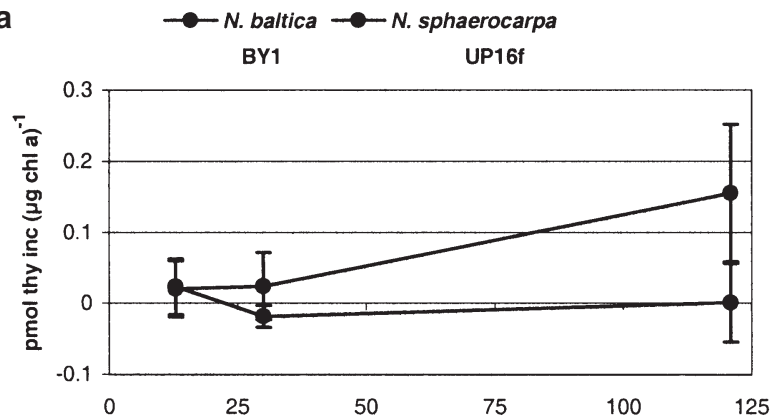

C

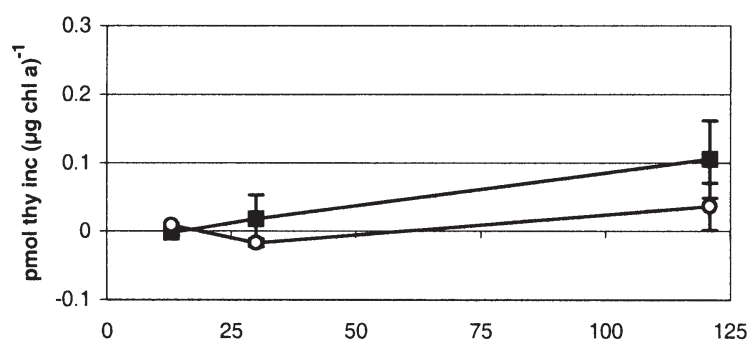

e

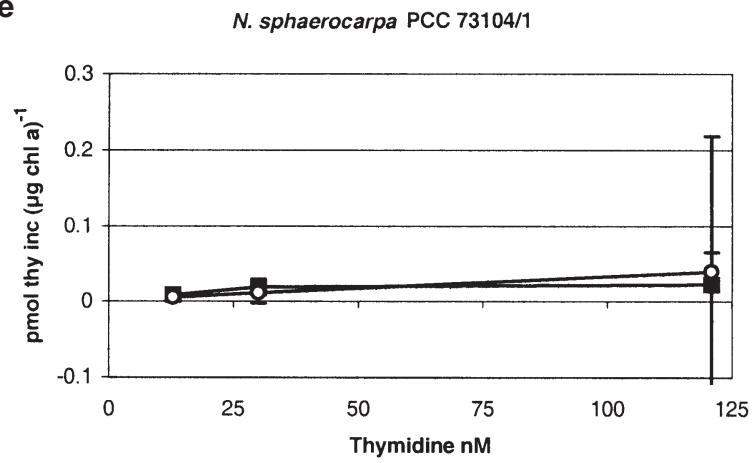

b

Nodularia sp. PCC 7804

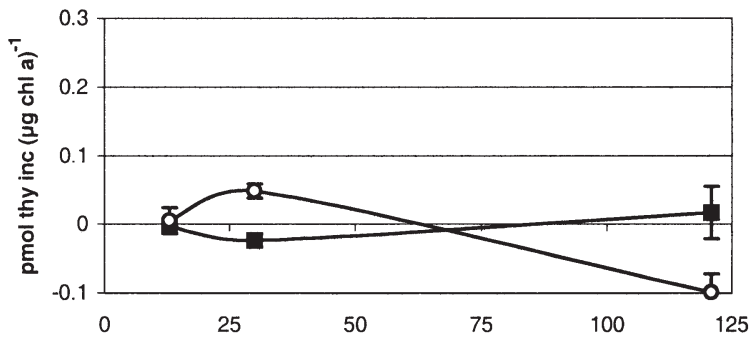

d

N. sphaerocarpa HKVV

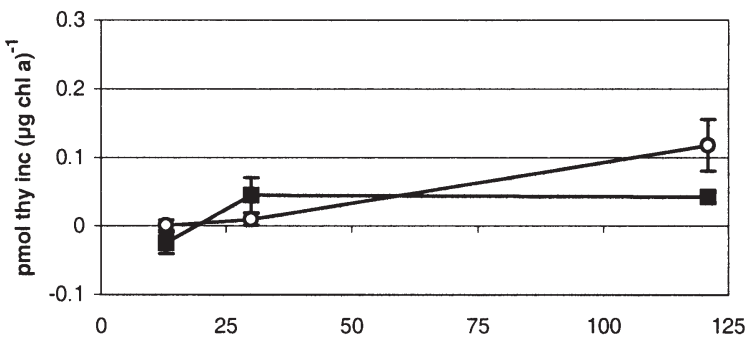

f

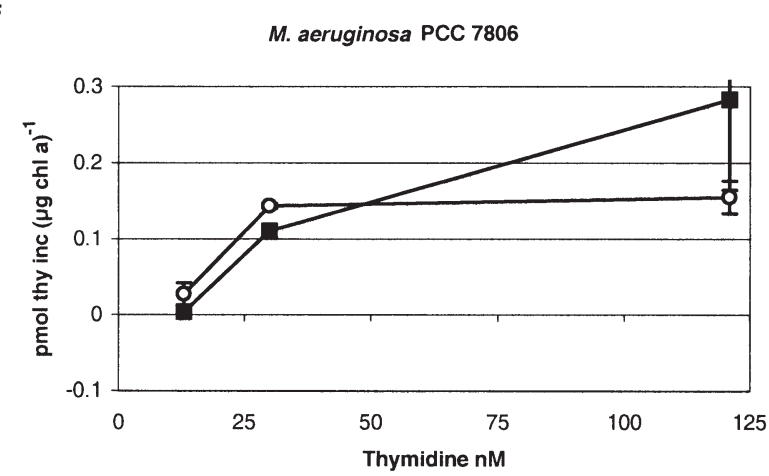

Fig. 2. Cyanobacterial (Nodularia spp. and Microcystis sp.) thymidine uptake velocity pmol thymidine $\mu g$ chl $a^{-1} \mathrm{~h}^{-1}$ at various thymidine concentrations. Cyanobacteria grown in nutrient-rich (ם) and nutrient-poor (O) growth media. Error bars \pm SD

(N. sphaerocarpa HKVV) and significantly lower (Nodularia sp. PCC 7804, M. aeruginosa PCC 7806) in cultures starved of nutrients compared to those grown in abundant nutrient conditions. We therefore conclude that cyanobacteria incorporate this small amino acid to use it as a building block for other cell products, such as proteins, as do heterotrophic bacteria. So far, the only cyanobacteria shown to incorporate leucine are Nodularia spp. (this study) and Microcystis sp. (Kamjunke \& Jähnichen 2000, this study). Experiments with Synechococcus sp. showed no incorporation at a leucine concentration of $24 \mathrm{nM}$ (Torreton \& Dufour 1996), nor was incorporation detected in experiments with coccoid cyanobacteria at $0.5 \mathrm{nM}$ concentration (Kirchman et al. 1985). However, more information is needed on potential leucine incorporation rates of other common cyanobacterial species, such as Anabaena spp. and Aphanizomenon spp. More experiments using axenic strains should be performed using leucine concentrations relevant to eutrophic environments, as it is possible that leucine is taken up by bloom-forming cyanobacteria other than Microcystis sp. and Nodularia spp. Obviously, the leucine incorporation method should not be used during cyanobacterial blooms.

Acknowledgements. This work was supported by grants from the Maj and Tor Nessling Foundation (S.H.) and the Academy of Finland (J.M.L. 52296, K.S. 46812). We highly appreciate the excellent technical assistance of Ms. Susanna Hyvärinen. Comments of 3 anonymous reviewers helped to improve the manuscript. 


\section{LITERATURE CITED}

Azam F, Fuhrman JA (1984) Measurement of bacterioplankton growth in the sea and its regulation by environmental conditions. In: Hobbie J, Williams PJleB (eds) Heterotrophic activity in the sea. Plenum Press, New York, p 179-196

Bern L (1985) Autoradiographic studies of (methyl- $\left.{ }^{3} \mathrm{H}\right)$-thymidine incorporation in a cyanobacterium (Microcystis wesenbergii)-bacterium association and in selected algae and bacteria. Appl Environ Microbiol 49:232-233

Børsheim KY (1990) Bacterial biomass and production rates in Gulf Stream front regions. Deep-Sea Res 8:1297-1309

Bratbak G, Heldal M, Thingstad TF, Riemann B, Haslund O (1992) Incorporation of viruses into the budget of microbial C-transfer. A first approach. Mar Ecol Prog Ser 83: 273-280

Davis CL (1989) Uptake and incorporation of thymidine by bacterial isolates from an upwelling environment. Appl Environ Microbiol 55:1267-1272

Fuhrman JA, Azam F (1980) Bacterioplankton secondary production estimates for coastal waters of British Columbia, Antarctica, and California. Appl Environ Microbiol 39: 1085-1095

Fuhrman JA, Azam F (1982) Thymidine incorporation as a measure of heterotrophic bacterioplankton production in marine surface waters: evaluation and field results. Mar Biol 66:109-120

Heinänen A, Kuparinen J (1992) Response of bacterial thymidine and leucine incorporation to nutrient $\left(\mathrm{NH}_{4}, \mathrm{PO}_{4}\right)$ and carbon (sucrose) enrichment. Arch Hydrobiol Beih Ergebn Limnol 37:241-251

Heinänen A, Kononen K, Kuosa H, Kuparinen J, Mäkelä K (1995) Bacterioplankton growth associated with physical fronts during a cyanobacterial bloom. Mar Ecol Prog Ser 116:233-245

Jeffrey WH, Paul JH (1988) Effect of 5-fluoro-2'-deoxyurine on $\left({ }^{3} \mathrm{H}\right)$-thymidine incorporation by bacterioplankton in the waters of Southwest Florida. Appl Environ Microbiol 54:331-336

Jeffrey WH, Paul JH (1990) Thymidine uptake, thymidine incorporation, and thymidine kinase activity in marine bacterium isolates. Appl Environ Microbiol 56:1367-1372

Kamjunke N, Jähnichen S (2000) Leucine incorporation by Microcystis aeruginosa. Limnol Oceanogr 45:741-743

Kirchman D, K'Nees E, Hodson R (1985) Leucine incorporation and its potential as a measure of protein synthesis by bacteria in natural aquatic systems. Appl Environ Microbiol 49:599-607

Laamanen MJ, Gugger MF, Lehtimäki JM, Haukka K, Sivonen K (2001) Diversity of toxic and non-toxic Nodularia (cyanobacteria) isolates and filaments from the Baltic Sea.

Editorial responsibility: William Li, Dartmouth, Nova Scotia, Canada
Appl Environ Microbiol 67:4638-4647

Lehtimäki J, Moisander P, Sivonen K, Kononen K (1997) Growth, nitrogen fixation, and nodularin production by two Baltic Sea cyanobacteria. Appl Environ Microbiol 63: $1647-1656$

Morán XAG, Massana R, Gasol JM (2001) Light conditions affect the measurement of oceanic bacterial production via leucine uptake. Appl Environ Microbiol 67:3795-3801

Moriarty DJ (1986) Measurement of bacterial growth rates in aquatic systems from rates of nucleic acid synthesis. Adv Microb Ecol 9:245-292

Pedrós-Alió C, García-Cantizano J, Calderon JI (1993) Bacterial production in anaerobic water columns. In: Kemp RF, Sherr BF, Sherr EB, Cole JJ (eds) Handbook of methods in aquatic microbial ecology. Lewis, Boca Raton, p 519-530

Pollard PC, Moriarty DJW (1984) Validity of the tritiated thymidine method for estimating bacterial growth rates: measurement of isotope dilution during DNA synthesis. Appl Environ Microbiol 48:1076-1083

Riemann B (1984) Determining growth rates of natural assemblages of freshwater bacteria by means of ${ }^{3} \mathrm{H}$-thymidine incorporation into DNA: comments on methodology. Arch Hydrobiol Beih Ergebn Limnol 19:76-80

Riemann B, Azam F (1992) Measurements of bacterial protein synthesis in aquatic environments by means of leucine incorporation. Mar Microb Food Webs 6:91-105

Rippka R (1988) Isolation and purification of cyanobacteria. In: Packer L, Glaxer AN (eds) Methods of enzymology, Vol 167, Cyanobacteria. Academic Press, San Diego, p 3-27

Robarts RD, Wicks RJ (1989) (Methyl- ${ }^{3} \mathrm{H}$ )-thymidine macromolecular incorporation and lipid labeling: their significance to DNA labeling during measurements of aquatic bacterial growth rate. Limnol Oceanogr 34:213-222

Robarts RD, Zohary T (1993) Fact or fiction-bacterial growth rates and production as determined by (methyl- ${ }^{3} \mathrm{H}$ )-thymidine? Adv Microb Ecol 13:371-425

Schuster S, Arrieta JM, Herndl GJ (1998) Adsorption of dissolved free amino acids on colloidal DOM enhances colloidal DOM utilization but reduces amino acid uptake by orders of magnitude in marine bacterioplankton. Mar Ecol Prog Ser 166:99-108

Simon M, Azam F (1989) Protein content and protein synthesis rates of planktonic marine bacteria. Mar Ecol Prog Ser 51:201-213

Sivonen K, Kononen K, Esala AL, Niemelä SI (1989) Toxicity and isolation of the cyanobacterium Nodularia spumigena from the southern Baltic Sea in 1986. Hydrobiologia 185: $3-8$

Torreton JP, Dufour P (1996) Bacterioplankton production determined by DNA synthesis, protein synthesis, and frequency of dividing cells in Tuamotu Atoll Lagoons and surrounding ocean. Microb Ecol 32:185-202

Submitted: November 22, 2001; Accepted: March 1, 2002 Proofs received from author(s): April 17, 2002 